\title{
Evolution of the Neuropeptide Y Receptor Family: Gene and Chromosome Duplications Deduced from the Cloning and Mapping of the Five Receptor Subtype Genes in Pig
}

\author{
Amanda Wraith, ${ }^{1}$ Anna Törnsten, ${ }^{2}$ Patrick Chardon, ${ }^{3}$ Ingrid Harbitz, ${ }^{4}$ \\ Bhanu P. Chowdhary, ${ }^{5}$ Leif Andersson, ${ }^{2}$ Lars-Gustav Lundin, ${ }^{6}$ and \\ Dan Larhammar ${ }^{1,7}$ \\ ${ }^{1}$ Department of Neuroscience, Unit of Pharmacology, Uppsala University, SE-751 24 Uppsala, Sweden; ${ }^{2}$ Department of \\ Animal Breeding and Genetics, Swedish University of Agricultural Sciences, SE-751 24 Uppsala, Sweden; ${ }^{3}$ Laboratoire de \\ Radiobiologie Appliquée, CEA-INRA, Jouy en Josas 78350, France; ${ }^{4}$ Department of Biochemistry, Physiology and Nutrition, \\ The Norwegian School of Veterinary Science, N-0033 Oslo, Norway; ${ }^{5}$ Division of Animal Genetics, The Royal Veterinary \& \\ Agricultural University, 1870 Frederiksberg, Denmark; ${ }^{6}$ Department of Medical Biochemistry and Microbiology, Uppsala \\ University, SE-751 23 Uppsala, Sweden
}

\begin{abstract}
Neuropeptide Y (NPY) receptors mediate a variety of physiological responses including feeding and vasoconstriction. To investigate the evolutionary events that have generated this receptor family, we have sequenced and determined the chromosomal localizations of all five presently known mammalian NPY receptor subtype genes in the domestic pig, Sus scrofa (SSC). The orthologs of the $Y_{1}$ and $Y_{2}$ subtypes display high amino acid sequence identities between pig, human, and mouse $(92 \%-94 \%)$, whereas the $Y_{4}, Y_{5}$, and $y_{6}$ subtypes display lower identities (76\%-87\%). The lower identity of $Y_{5}$ is due to high sequence divergence in the large third intracellular loop. The NPYIR, NPY2R, and NPY5R receptor genes were localized to SSC8, the NPY4R to SSC14, and NPY6R to SSC2. Our comparisons strongly suggest that the tight cluster of NPY1R, NPY2R, and NPY5R on human chromosome 4 (HSA4) represents the ancestral configuration, whereas the porcine cluster has been split by two inversions on SSC8. These 3 genes, along with adjacent genes from 14 other gene families, form a cluster on HSA4 with extensive similarities to a cluster on HSA5, where NPY6R and $>13$ other paralogs reside, as well as another large cluster on HSA10 that includes NPY4R. Thus, these gene families have expanded through large-scale duplications. The sequence comparisons show that the NPY receptor triplet NPYIR-NPY2R-NPY5R existed before these large-scale duplications.
\end{abstract}

[Sequence data for this article were deposited with the GenBank data library under accession nos. AF106081, PID g6457648 (for Pig Y1 sequence); accession nos. AF106082, PID g4249727 (for Pig Y2 sequence); accession no. AF227955 (for Pig Y4 sequence); accession nos. AF106083, PID g4249729 (for Pig Y5 sequence); accession no. AF227956 (for Pig Y6 sequence).]

The endogenous ligands of neuropeptide Y (NPY) receptors are a family of structurally related peptides that includes NPY, peptide YY (PYY), and pancreatic polypeptide (PP). Each ligand consists of 36 amino acids that adopt a hairpin-like structure called a PP-fold (Fuhlendorff et al. 1990). NPY and PYY are the ancestral peptides, whereas the PP gene is a later duplication of PYY (Hort et al. 1995; Larhammar 1996). NPY is involved in the regulation of many physiological activities, such as food intake, blood pressure, and circadian rhythms. PYY and PP are mainly localized to endocrine cells and influence gastric and pancreatic secretion, and gastric and intestinal motility (Gehlert 1998).

${ }^{7}$ Corresponding author.

E-MAIL Dan.Larhammar@neuro.uu.se; FAX 46-18 511540.
NPY receptors belong to class A of the G proteincoupled receptor superfamily, that is, the rhodopsinlike receptors. The intracellular loops of these receptors interact with $\mathrm{G}$ proteins, which evoke a variety of second messenger responses (Bockaert and Pin 1999). There are currently five cloned NPY receptor subtypes in mammals, $\mathrm{Y}_{1}(N P Y 1 R), \mathrm{Y}_{2}$ (NPY2R), $\mathrm{Y}_{4}$ (NPY4R or PPYR1), $\mathrm{Y}_{5}$ (NPY5R), and $\mathrm{y}_{6}$ (NPY6R) (Blomqvist and Herzog 1997; Michel et al. 1998). The $Y_{3}$ receptor has not been cloned but has been identified on the basis of its unique binding profile in vivo (Lee and Miller 1998). Early reports that a receptor clone displayed $Y_{3^{-}}$ like binding (Rimland et al. 1991) were shown to be incorrect (Herzog et al. 1993b; Jazin et al. 1993). This receptor was later found to be a chemokine receptor, now designated CXCR4, which binds the ligand SDF-1 
(Loetscher et al. 1994; Feng et al. 1996; Oberlin et al. 1996).

NPY and PYY display high affinity for $\mathrm{Y}_{1}, \mathrm{Y}_{2}$, and $\mathrm{Y}_{5}$ receptor subtypes, which show very low sequence identity to each other ( 30\%), suggesting that they are quite ancient duplications (Larhammar et al. 1998). PP preferentially binds to the $\mathrm{Y}_{4}$ receptor, whereas $\mathrm{y}_{6}$ (written with a lower case $y$ as it has no physiological correlate) is a pseudogene in human and has very different pharmacological properties between mouse and rabbit (Gregor et al. 1996; Matsumoto et al. 1996). The human (HSA) genes NPY1R, NPY2R, and NPY5R are clustered on HSA4q31-4q32 (Herzog et al. 1993a; Gerald et al. 1996; Lutz et al. 1997a). In the mouse (MMU), the corresponding region is split over the two chromosomes, MMU3 and MMU8 (Lutz et al. 1997a, 1997b). The NPY4R and NPY6R genes are most similar to $N P Y 1 R$, but the human genes are localized to two other chromosomes, HSA10q11.2-q21 and HSA5q31 (Gregor et al. 1996; Lutz et al. 1997a, 1997b; Rose et al. 1997). The mouse NPY4R and NPY6R genes also localize to two other chromosomes, MMU14 and MMU18, respectively (Lutz et al. 1997b).

Gene families may expand by various duplication mechanisms, and these duplications provide opportunities for subsequent functional differentiation. It has been proposed that early in vertebrate evolution, the ancestral genome underwent large-scale duplications, either genome doublings (tetraploidizations) or at least extensive duplications of chromosomal segments (Lundin 1993; Holland et al. 1994; Sidow 1996). This is supported by the presence of three to four copies of several large gene clusters in the mammalian genome, for example the homeobox (HOX) clusters are localized on human chromosomes HSA2, HSA7, HSA12, and HSA17 (Schughart et al. 1989; Holland et al. 1994; Ruddle et al. 1994). These large-scale duplications presumably facilitated the evolution of the complex anatomical organization of vertebrates, particularly the gnathostomes (jawed vertebrates) (Holland et al. 1994; Sidow 1996). These and several other examples show that information about chromosomal localization is an important complement to sequence-based analyses to deduce gene relationships and species phylogenies. For example, NPY and PYY have arisen from a common ancestor through a chromosomal duplication, with the NPY gene (HSA7q15.1) close to the HOXA cluster (HSA7p15-p14), whereas PYY (HSA17q21.1) is close to the HOXB cluster (HSA17q21-q22) (Larhammar et al. 1997). The third member, PP, arose through a local and more recent tandem duplication of PYY (Hort et al. 1995; Larhammar 1996). These relationships are not obvious from overall sequence identity, as the most recent member, $\mathrm{PP}$, has the highest replacement rate (Larhammar 1996).

The NPY receptor genes display modest sequence identity between subtypes (31\%-51\%) (Michel et al. 1998), have widely differing substitution rates between subtypes (Lundell et al. 1996), and display different chromosomal localizations between human and mouse. Together, these features have hindered investigations into their evolution. We decided to use a representative from a third order of mammals, the domestic pig (Sus scrofa) to enhance investigations into the evolution of this receptor family. The pig gene map is relatively dense (Yerle et al. 1997) compared with many other mammals (excluding human or mouse) (O'Brien et al. 1999), it is well characterized with respect to the role of NPY in cardiovascular regulation (Malmstrom et al. 1998) and is interesting for studying the affects of the NPY system in feeding and metabolism.

We report here the isolation of all currently identified NPY receptor genes from the pig, the receptor sequences, and their chromosomal localization within the genome. (We have reported previously the $\mathrm{Y}_{5}$ mapping; Tornsten et al. 1998.) This has enabled us to deduce the ancestral organization for the NPY receptor genes and to trace the evolution of three large chromosomal segments.

\section{RESULTS}

\section{Cloning and Sequence Analysis of Porcine NPY Receptor Genes}

Porcine genomic clones were isolated from phage (NPY1R, NPY4R, and NPY6R) or BAC (NPY2R) libraries. The NPY5R-containing phage clone had been isolated and mapped previously (Tornsten et al. 1998). Coding regions were sequenced for each of the porcine genes and the predicted proteins were used in sequence alignments with the other two species for which all five sequences and mapping data are available, namely, human and mouse. The sequence identities between the species are shown in Table 1 . The $\mathrm{Y}_{4}$ subtype displays the lowest identities between species of the functional receptors. The $\mathrm{Y}_{5}$ subtype also displays low sequence identities between species, with most of the differences arising within the third intracellular loop, which is at least four times longer than those of the other subtypes. Removal of this region from the alignment $\left(N P Y 5 R^{*}\right)$ makes the level of sequence identity comparable with $Y_{1}$ and $Y_{2}$ (Table 1).

Sequence (nucleotide) alignment of the porcine $\mathrm{y}_{6}$ subtype revealed two 2-bp deletions within the third extracellular loop and carboxy-terminal tail, which result in early stop codons, presumably resulting in a nonfunctional receptor. The human $\mathrm{y}_{6}$ is also a pseudogene and contains a different 1-bp deletion, also resulting in a truncated receptor (Gregor et al. 1996; Matsumoto et al. 1996; Rose et al. 1997).

The porcine NPY1R is the only subtype to have an 
Table 1. Amino Acid Sequence Identities Between Species

\begin{tabular}{lccc}
\hline & \multicolumn{3}{c}{ Sequence identities } \\
\cline { 2 - 4 } $\begin{array}{l}\text { Receptor } \\
\text { subtype }\end{array}$ & pig:human & pig:mouse & human:mouse \\
\hline NPY1R & 94.5 & 92.4 & 92.4 \\
NPY2R & 93.7 & 93.7 & 92.9 \\
NPY4R & 85.9 & 77.1 & 75.7 \\
NPY5R & 85.4 & 81.2 & 87.6 \\
NPY5R & 93.5 & 89.0 & 91.9 \\
NPY6R & 80.9 & 78.4 & 80.9 \\
\hline
\end{tabular}

Amino acid identities are given for aligned NPY receptors over full coding regions, in the pig, human (accession nos. M88461, NM_000910, Z66526, NM_006174, NM_006173), and mouse (accession nos. Z18280, D86238, U40189, AF049329, U58367). NPY5R* represents the NPY5R sequences without the third intracellular loop in the alignment.

intron within the coding region. This was observed in the pig in agreement with all other genomic NPY1R sequences available, including human (GenBank accession no. A26126) and guinea pig (accession no. AF135061). Alignment of the porcine intron (108 bp) with the human (97 bp) and the guinea pig intron (105 bp) reveals $71 \%$ and $74 \%$ identity, respectively (alignments not shown). This is relatively high in comparison with the degree of identity of the coding regions of this receptor, which is $87 \%$ between pig and human and $86 \%$ between pig and guinea pig at the nucleotide level.

The amino acid sequences of the five cloned porcine receptors were used to construct a phylogenetic

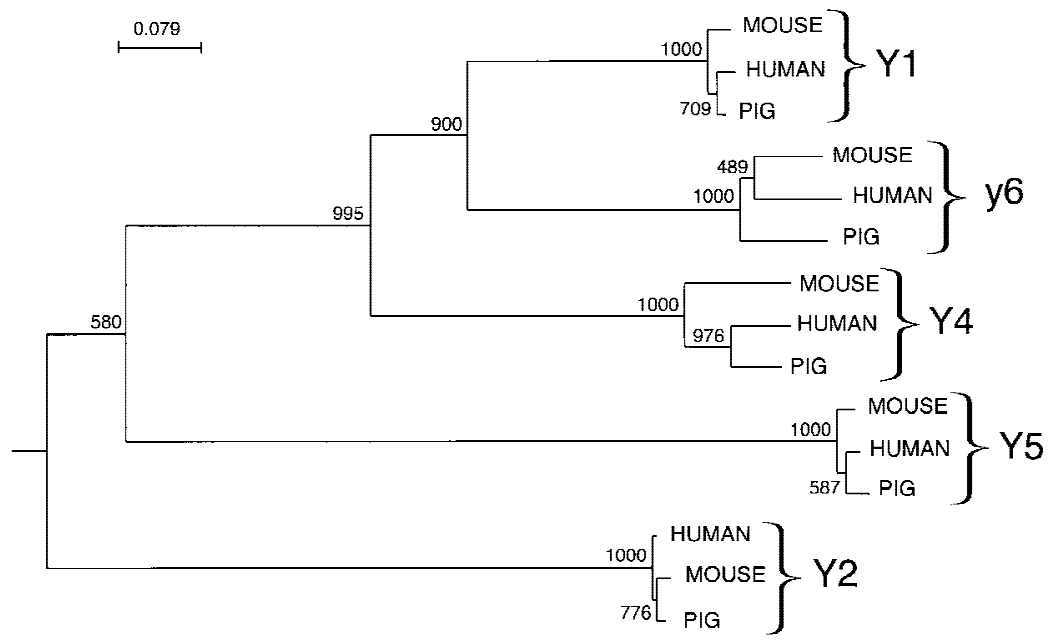

Figure 1 A phylogenetic tree for the porcine, mouse, and human NPY receptor sequences from transmembrane 1 to transmembrane 7 without the third intracellular loop (252-258 amino acids in total). The sequences were aligned using the CLUSTAL method and the tree constructed using the neighbor-joining method with the Caenorhabditis elegans NPY receptor-like sequence (GenBank accession no. AAA93419) as the outgroup. The strength of the tree topology was tested by bootstrap analysis with 1000 replications; the values are shown above each branch. tree including the human and mouse orthologs (Fig. 1). The tree is based on the region spanning transmembrane 1 to transmembrane 7 , because the terminal regions differ extensively between subtypes. The third intracellular loop was also excluded because of the high variability in the sequence and the length, making alignment difficult. Each subtype forms a discrete branch within the tree with full bootstrap support. The $\mathrm{Y}_{1}, \mathrm{y}_{6}$, and $\mathrm{Y}_{4}$ subtypes form a tighter cluster than the more distant $\mathrm{Y}_{5}$ and $\mathrm{Y}_{2}$.

\section{Localization of NPY Receptors}

The genes NPY1R, NPY2R, and NPY5R were localized to SSC8 by FISH mapping. The human orthologs are all found on HSA4, which corresponds to SSC8 as reported previously (Johansson et al. 1995; Rettenberger et al. 1995; Fronicke et al. 1996; Goureau et al. 1996). The phage containing NPY1R mapped to SSC8p11, proximal to the KIT gene (Fig. 2). This localization is the same as our recent FISH assignment of the NPY5R gene (Tornsten et al. 1998). However, the NPY2R BAC clone mapped on the other side of the centromere to the proximal end of SSC8q21 (Fig. 2).

The phage clone containing NPY4R was FISH mapped to SSC14q25. This is in agreement with previous comparative painting/mapping studies showing that this region of SSC14q corresponds to HSA10q (Johansson et al. 1995; Rettenberger et al. 1995; Fronicke et al. 1996; Goureau et al. 1996), in which human NPY4R is located (HSA10q11) (Lutz et al. 1997b).

NPY6R was mapped using a somatic cell hybrid panel (Yerle et al. 1996) because of problems with FISH mapping using the NPY6R clone. The gene was ascribed to SSC2q24-q29 with a probability of 0.9 and a correlation coefficient of 1. This region of SSC2 shows synteny to HSA5q (Johansson et al. 1995; Rettenberger et al. 1995; Fronicke et al. 1996; Goureau et al. 1996), in which the human homolog has been localized (HSA5q31).

\section{Fiber-FISH Mapping of NPYIR and NPY5R}

The NPY1R and NPY5R genes mapped to the same location on metaphase chromosomes, and their order in relation to the centromere could not be resolved by dual color FISH. In addition, the orientation of the two genes relative to the centromere could not be determined in the absence of a closely located marker.

Using fiber-FISH, both probes showed distinct and well-separated fluorescent signals on mechanically stretched DNA fibers. The probe size 


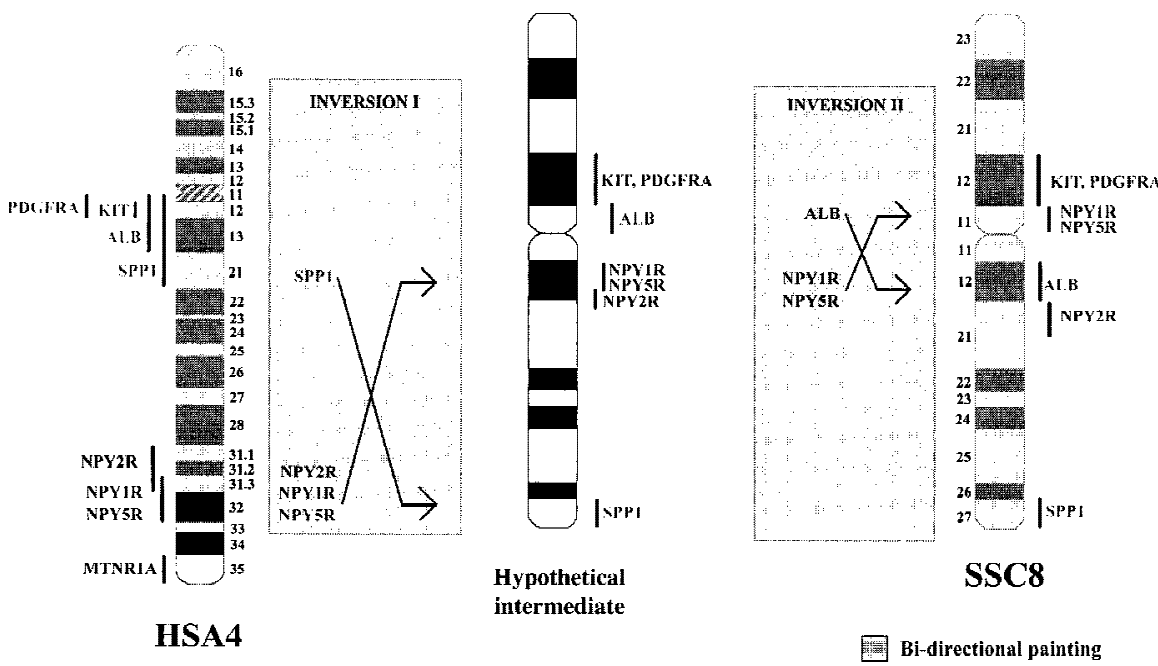

Figure 2 Proposed intrachromosomal rearrangements of SSC8 with reference to HSA4, (data taken from the Genome database, http://gdbwww.gdb.org/ and Laboratoire de Génétique Cellulaire, http://www.toulouse.inra.fr/lgc/pig/cyto/cyto.htm). Two inversions are postulated: a large inversion of SPP1-NPY receptor cluster, followed by a smaller inversion of $A L B-N P Y 1 R$, NPY5R. The shading indicates the synteny between HSA4 and SSC8 as identified through bidirectional painting (Goureau et al. 1996).

standard (PSS) and Watson-Crick standard (WCS) approaches were used to estimate the physical distance between them (see Sjoberg et al. 1997 for details). Using the insert size of NPY5R $(17 \mathrm{~kb})$ as a standard, the two probes were found to be separated by $22 \mathrm{~kb}$ (S.D. $\pm 7 \mathrm{~kb}, n=50$ ). The WCS approach, where 1 $\mu \mathrm{m}=2941 \mathrm{bp}$, gave a similar estimate of $23 \mathrm{~kb}$ (s.D. $\pm 8 \mathrm{~kb}, n=50$ ).

Human NPY1R and NPY5R are encoded on opposing strands. With the assumption that this is also the situation in the pig, we attempted to further refine the distance in the pig between these receptor genes. To estimate the distances between the phage arms and the coding region of each of the receptor genes, we used a phage primer in combination with a reverse genespecific primer in long-range PCR. We found the distance from the phage arm to the start codon was $4.1 \mathrm{~kb}$ for NPY5R and $7.2 \mathrm{~kb}$ for the NPY1R. This allows an estimate of the total distance between the two coding regions in the pig of $\sim 33 \mathrm{~kb}$, which is considerably larger than that between the human genes $(23 \mathrm{~kb})$.

\section{Comparative Analysis of NPY1R, NPY2R, and NPY5R}

The addition of the NPY receptor genes to the pighuman comparative maps expands the known conserved synteny of SSC8 and HSA4 (Fig. 2). An inversion on SSC8 disrupts the PDGFRA-KIT-ALB-SPP1 cluster that is seen on HSA4q as reported previously (Ellegren et al. 1993; Johansson et al. 1995). The NPY receptor cluster would appear to be at the lower boundary of this inversion. This is further supported with bidirectional painting, which shows that the synteny between
SSC 8 and HSA 4 stops at HSA4q31.3 (Goureau et al. 1996). We also propose that a second smaller inversion of the segment from $A L B$ to NPY1RNPY5R cluster followed this first larger inversion to explain the disruption of the NPY receptor gene cluster (Fig. 2).

By including the mouse (MMU5) in this comparative analysis, we show that human and mouse have the same PDGFRA-KIT-ALB-SPP1 gene cluster organization; this order is likely to be the more ancestral gene order, rather than that seen on SSC8.

\section{Paralogous Chromosomal Regions}

An in silico search of the three chromosomes (HSA4, HSA5q, HSA10q), on which the NPY receptor paralogs map in human, revealed several other gene families that also have paralogs distributed over these three chromosomes (Fig. 3). The addition of these gene families to those identified previously on these chromosomes (Lundin 1993; Pebusque et al. 1998), provides further support that these chromosomal regions share a common ancestor and that largescale duplications have led to the expansion of the gene families. Several other chromosomal regions were also implicated, including a region on HSA8 (six genes) and a small region on HSA2p (three genes) (Fig. 3). For a few gene families, some members were excluded when sequence analysis suggested that they were very ancient or very recent duplications (references listed in the legend to Fig. 3).

\section{DISCUSSION}

Two rounds of genome duplication have been proposed to have occurred during the early evolution of vertebrates, before the origin of the gnathostomes (Lundin 1993; Holland et al. 1994; Sidow 1996). Some evidence against this idea was reported recently (Hughes 1999) but was based solely on studies of tree topology of several developmentally important gene families. Here we demonstrate the importance of also considering other types of information such as chromosomal localization, gene loss after duplication, and variable substitution rates within gene families. However, chromosomal comparisons are complicated by differences between the human and mouse genetic maps, the mammals with the most detailed genetic maps. Therefore, to study the evolution of the NPY 


\begin{tabular}{|c|c|c|c|c|c|}
\hline & SA & HSAS & HSA 10 & HSA8 & OTHER \\
\hline HOMEOBOX HOMOLOG ${ }^{\star}$ & MSX1 & $\underset{\substack{\text { MSX2 } \\
034+35}}{0}$ & & & \\
\hline $\begin{array}{l}\text { FIBROBLAST GROWTH } \\
\text { FACTOR RECEPTOR }\end{array}$ & FGFR3 & $\begin{array}{l}\text { FGFR4 } \\
\text { as3-qeer }\end{array}$ & $\begin{array}{l}\text { FGFR2 } \\
4253.2826\end{array}$ & $\begin{array}{l}\text { FGFR1 } \\
\text { p12 }\end{array}$ & $\begin{array}{l}\text { FGFR6 } \\
\text { G921.3 }\end{array}$ \\
\hline ADRENERGIC RECEPTOR & $\begin{array}{l}\text { ADRA2C } \\
\text { sit3.p.15 }\end{array}$ & 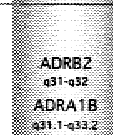 & $\begin{array}{c}\text { ADRA2A } \\
\text { a25 } \\
\text { ADRB1 } \\
925\end{array}$ & 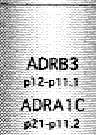 & $\begin{array}{c}\text { ADRA2B } \\
2 \mathrm{p} 13-\mathrm{q} 13 \\
\text { ADRA1A } \\
20 \mathrm{pq}\end{array}$ \\
\hline DOPAMINE RECEPTOR & $\begin{array}{c}\text { DRDS } \\
\text { pis.3pis.15: }\end{array}$ & 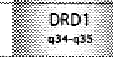 & & & \\
\hline GABA RECEPTOR ${ }^{*}$ & $\underset{\substack{\text { GABRA2 } \\
013-912}}{2}$ & 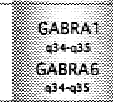 & & & $\begin{array}{l}\text { GABRA3 } \\
\text { Xa28 } \\
\text { GABRAS } \\
15911-913\end{array}$ \\
\hline $\begin{array}{l}\text { RECEPTOR TYROSINE } \\
\text { KINASE }\end{array}$ & $\begin{array}{c}\text { PDGFRA } \\
\text { 911-012 } \\
\text { KIT } \\
912 \\
\text { KDR } \\
912 \\
912\end{array}$ & 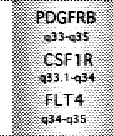 & & & $\begin{array}{l}\text { FLT3 } \\
13912 \\
F L T 1 \\
\text { } 13912\end{array}$ \\
\hline SYNUCLEIN ${ }^{*}$ & 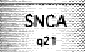 & $\underbrace{S N C B}_{435}$ & $\begin{array}{c}\text { SNCG } \\
{ }_{223}\end{array}$ & & \\
\hline ANNEXIN & $\begin{array}{l}\text { ANXA3 } \\
\text { Q13-0.22 }\end{array}$ & & $\begin{array}{l}\text { ANXAB } \\
9112.2 \\
\text { ANXA11 } \\
922-2923\end{array}$ & & $\underset{2 \mathrm{p} 13}{\mathrm{ANX} 13}$ \\
\hline $\begin{array}{l}\text { BONE MORPHOGENETIC } \\
\text { PROTEIN RECEPTOR }\end{array}$ & $\begin{array}{l}\text { 8MPR1B } \\
623-24\end{array}$ & & ${ }_{9 M P R 1 A}$ & & \\
\hline $\begin{array}{l}\text { EARLY GROWTH } \\
\text { RESPONSE }\end{array}$ & & $\begin{array}{l}\text { EGR1 } \\
a 31.1\end{array}$ & $\begin{array}{l}\text { EGR2 } \\
{ }_{9221.1}\end{array}$ & EGR3 & \\
\hline $\begin{array}{l}\text { HOMEODOMAIN } \\
\text { TRANSCRIPTION FACTOR* }\end{array}$ & $\begin{array}{l}\text { P1TX2 } \\
\text { P25-427 }\end{array}$ & 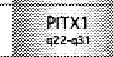 & $\begin{array}{l}\text { PITX3 } \\
225\end{array}$ & & \\
\hline ANKYRIN & $\begin{array}{l}\text { ANK2 } \\
\text { a25-927 }\end{array}$ & & $\begin{array}{c}\text { ANK3 } \\
\text { q21 }\end{array}$ & ANK1 & \\
\hline $\begin{array}{l}\text { N-DEACETYLASE/N- } \\
\text { SULFOTRANSFERASES }\end{array}$ & & $\begin{array}{l}\text { NOST1 } \\
(32-433.1\end{array}$ & ${ }_{922}^{\text {NDST2 }}$ & & \\
\hline ANNEXIN & $\begin{array}{l}\text { ANXAS } \\
226-28 \\
\end{array}$ & ANXA6 & $\begin{array}{l}\text { ANXA7 } \\
\text { A21.1-2021:2 }\end{array}$ & $\begin{array}{l}\text { ANXA13 } \\
.24+1.9242\end{array}$ & \\
\hline $\begin{array}{l}\text { TRANSFORMING GROWTH } \\
\text { FACTR \& TRANSDUCER }\end{array}$ & $\underset{928}{\mathrm{MADH1}}$ & $\begin{array}{c}\text { MADH5 } \\
\text { 431 }\end{array}$ & & & \\
\hline NPY RECEPTOR & $\begin{array}{c}\text { NPY5R } \\
\text { al-31-32 } \\
\text { NPY1R } \\
.931 .3-32 \\
\text { NP2R } \\
931\end{array}$ & $\begin{array}{c}\text { NPYGR } \\
{ }_{931}\end{array}$ & $\begin{array}{l}\text { NPY4R } \\
\text { a11.2-21.2. }\end{array}$ & & \\
\hline $\begin{array}{l}\text { GLUTAMATE RECEPTOR, } \\
\text { IONOTROPHIC }\end{array}$ & ${ }_{43212-933}^{\text {GRIA2 }}$ & 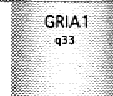 & & & $\begin{array}{c}\text { GRIA3 } \\
\text { Gazs-26 } \\
\text { GRIA4 } \\
11222-233\end{array}$ \\
\hline GLYCINE RECEPTOR ${ }^{*}$ & $\begin{array}{l}\text { GLRA3 } \\
4933-34\end{array}$ & GLRA1 & & & GLRA2 \\
\hline HEXOKINASE & & $\begin{array}{l}\mathrm{HKK3} \\
{ }_{9352}\end{array}$ & $\begin{array}{l}\mathrm{HK1} \\
922\end{array}$ & & $\begin{array}{l}\mathrm{HK2} \\
2 \mathrm{p} 13.1\end{array}$ \\
\hline
\end{tabular}

Figure 3 Gene families with members localized on HSA4, HSA5q, and HSA $10 q$ forming part of three paralogous chromosomal groups. Another paralogous region is implicated on $\mathrm{HSA} 8$, along with several genes localizing to "other" chromosomes, but not forming a large cluster. The asterisk (*) indicates that we did not find a reference phylogenetic tree for this gene family; for the other gene families the following references were used: hexokinase (Cardenas et al. 1998); ankyrins (Pebusque et al. 1998); dopamine receptors (Fryxell 1995; Cardinaud et al. 1997); annexins (Morgan et al. 1998); adrenergic receptors (Fryxell 1995); BMP receptors and TGF- $\beta$ signal transducers (Newfeld et al. 1999); glycine receptors (David-Watine et al. 1999); receptor tyrosine kinases (Rousset et al. 1995); FGF receptors (Coulier et al. 1997); EGFs (Hughes 1999). The gene order is according to that on HSA4 and is not always the same for the other chromosomes. Data were taken from the Genome Database (http://gdbwww.gdb.org/) and OMIM (http://www.ncbi.nlm.nih. gov/Omim/). The first listed genomic localization was used if multiple localizations had been made, or the HUGO approved localization. (Please note that NPY4R is designated as PPYR1 by HUGO.)

receptor family, we have isolated all of the currently identified mammalian NPY receptor genes in the pig. We report here comparative analyses of these sequences and genomic localizations, which help resolve the evolution of the NPY receptor family and has implications for ancestral chromosome arrangements.

The porcine NPY receptors $Y_{1}$ and $Y_{2}$ each displays high amino acid identities (92.4\%$94.5 \%)$ to the human and mouse orthologs (Table 1; Fig. 1). The NPY1R is the only NPY receptor gene to contain an intron within the coding region. Comparison of the pig intron with the human and guinea pig sequences revealed an unexpectedly high identity in comparison with the coding region of the receptors at the nucleotide level, suggesting that there are conserving selection pressures acting on the intron. The $\mathrm{Y}_{5}$ receptor is equally well conserved as $Y_{1}$ and $Y_{2}$, with the exception of the large third intracellular loop. The larger size of the loop may facilitate many types of modulatory interactions and the sequence variability may imply species differences in second messenger signaling.

The $\mathrm{Y}_{4}$ and $\mathrm{y}_{6}$ receptors are less conserved between species, $76 \%-86 \%$ and $78 \%-81 \%$, respectively (Table 1 ; Fig. 1). The $\mathrm{Y}_{4}$ subtype appears to be the fastest evolving functional receptor subtype and, interestingly, the only cloned NPY receptor with higher affinity for PP than NPY or PYY. PP, the most recent member of the PP-fold family of peptides arose in early tetrapod evolution and is one of the fastest evolving peptides (Larhammar 1996). The frameshifts in the porcine NPY6R probably result in a loss of function, like the human ortholog. After correction of the frameshift mutation by site-directed mutagenesis, the human $\mathrm{y}_{6}$ still did not show specific binding in in vitro assays (Gregor et al. 1996). Thus, the frameshift in the human NPY6R may be secondary to an earlier causal mutation, which is probably also the situation for the porcine NPY6R. The only species where $\mathrm{y}_{6}$ has been found to be functional are the mouse (Gregor et al. 1996) and rabbit (Matsumoto et al. 1996), which display widely differing pharmacological profiles. In the rat, Southern and Northern hybridizations indicate that this receptor gene is absent (Burkhoff et al. 1998). Together, these results suggest that the $\mathrm{y}_{6}$ subtype may have little, if any, functional importance even in mouse and rabbit, in which it is still capable of binding NPY-family peptides.

The chromosomal position of the porcine NPY receptor genes were determined, and all five were found to map to regions within the pig genome that had been identified previously by ZOO-FISH studies to display synteny with human chromosomes (Goureau 
et al. 1996; Fig. 2). The human NPY1R and NPY5R coding regions are reported to be $23 \mathrm{~kb}$ apart and to have overlapping exons that are transcribed in opposite directions (Herzog et al. 1997). This close proximity of NPY1R and NPY5R is conserved in the pig and in mouse, in which they are adjacent loci (Lutz et al. 1997b).

A comparative analysis shows that the same PDGFRA-KIT-ALB-SPP1 cluster is found on HSA4 and MMU5, respectively, suggesting that this is the likely ancestral gene arrangement (Fig. 2). Porcine SSC8 diverges from this gene arrangement, presumably a result of intra-chromosomal inversions occurring after the divergence from a common mammalian ancestor. If the inversions on SSC8, including the NPY receptor genes, are theoretically reversed to obtain the conserved PDGFRA-KIT-ALB-SPP1 cluster, NPY1R, NPY2R, and NPY5R also become clustered in the pig, as is the case on HSA4q. Consequently, these three NPY receptor genes were most probably clustered in the ancestor, and were separated presumably by a translocation in the mouse. Preliminary results from FISH mapping of NPY1R, NPY2R, and NPY5R in chicken indicate that they may also be clustered, providing further support for this scenario (S. Mikko and A. Tornsten, unpubl.). Thus, we propose that HSA4q is likely to still exhibit the common ancestral gene order for this region of the genome. With the recent mapping of GRIA2, UCP1, PEPS3, GNRHR, and FGF2 on SSC8 (Larsen et al. 1999; Rohrer 1999), our proposed scenario receives further support. However, more detailed gene ordering will be required for a definitive analysis. It is possible that other, more complicated rearrangements may have taken place, but the scheme outlined above appears to us as the most parsimonious with the currently available data.

From the phylogenetic tree of the NPY receptor family (Fig. 1), we propose that two local gene duplication events of an ancestral gene gave rise to NPY1R, NPY2R, and NPY5R. This is concluded as these three genes are exceptionally different from each other (they differ more than any other $\mathrm{G}$ protein-coupled receptors that still bind the same peptide ligands), yet each evolves very slowly as shown by the modest species differences in the tree (Fig. 1). This was followed by large-scale (chromosomal or genome) duplication events leading to the paralogous chromosomal regions that we see now, with NPY1R, NPY2R, and NPY5R on HSA4q, NPY4R on HSA10q, and NPY6R on HSA5q (Fig. 4). NPY4R and NPY6R, are clearly most similar to NPY1R although they reside on different chromosomes and both evolve quite rapidly to be $\mathrm{G}$ protein-coupled receptors, as shown by the more extensive species differences in Table 1. This scenario is consistent with that proposed by Pebusque (1998) for the adrenergic receptor genes, another $G$ protein-coupled receptor

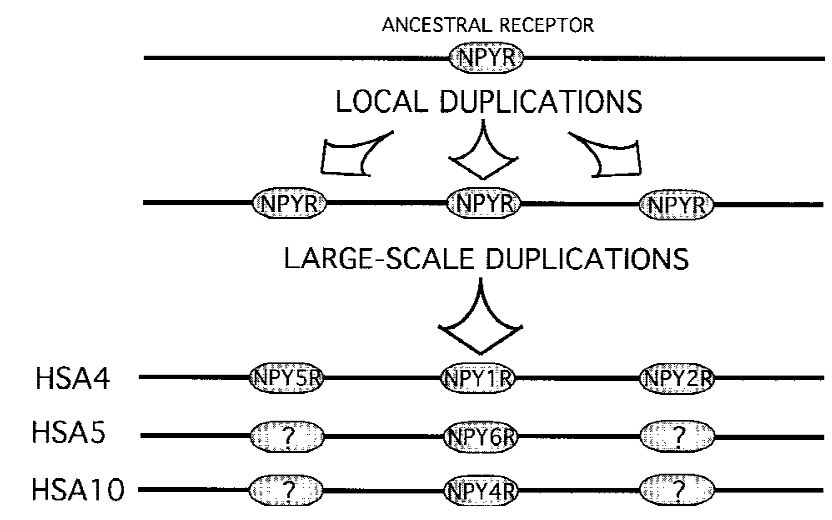

Figure 4 The proposed scenario for the evolution of the NPY receptor gene family. Initially two local duplications generated the ancestors of NPY1R, NPY2R, and NPY5R. Then, two large-scale duplications followed, arriving at the current gene arrangement. Genes with question marks may have been lost or have not yet been discovered.

family, which shares the same paralogous chromosomal regions (Fig. 3). As shown in Figure 3, we have identified several additional genes in these chromosomal segments, thereby adding firm support to the scheme of the entire segment being duplicated. Note that each of the gene clusters for the glycine receptors, GABA receptors, and glutamate receptors, consists of multiple genes, of which only one paralogous grouping is shown (L. Lundin and D. Larhammar, unpubl.).

The NPY receptor family and the other gene families on HSA4, HSA5q, and HSA10q provide strong evidence for large-scale duplications. Together with a quartet of related chromosomal segments in which the HOX clusters reside (HSA2, HSA7, HSA12, and HSA17) (Holland et al. 1994; Ruddle et al. 1994; Schughart et al. 1989) and a triplet including HSA1, HSA6, and HSA9 (Katsanis et al. 1996), tetraploidization might be the most parsimonious assumption, particularly if many of the daughter genes were subsequently lost. An example of this type of gene loss was suggested for the teleost fish that have undergone a recent tetraploidization that resulted in seven Hox cluster chromosomes in the zebrafish, of which only four seem to remain in the puffer fish (Amores et al. 1998). The NPY receptor tree shows that replacement rates may differ dramatically among closely related members of a gene family such as NPY1R, NPY4R, and NPY6R. These variable replacement rates show that gene localization is an important additional criterion to resolve the evolution of gene families. The uneven replacement rates make it difficult to determine the order of chromosome duplications that led to the present segments on human chromosomes HSA4, HSA5, and HSA10. The NPY receptor family sequence tree supports HSA4 and HSA5 to be a more recent duplication as NPY6R is closer to NPY1R than either of these is to NPY4R on HSA5, but additional information from other gene families would 
be required to resolve the order and timing of these events.

As the gene triplet, NPY1R, NPY2R, and NPY5R arose prior to the chromosome duplications, it follows that the chromosomes with NPY4R and NPY6R should carry paralogs of the other two genes, NPY2R and NPY5R (Fig. 4). Possibly some, if not all four of those copies may have been lost, but in consideration of existing pharmacological evidence for additional NPY receptor subtypes, it is tempting to postulate that additional NPY receptor genes may remain to be discovered in mammals (Blomqvist and Herzog 1997; O'Shea et al. 1997). A recently discovered fourth $Y_{1}$-like gene, Ya in zebrafish, with a seemingly distinct chromosomal localization from comparative analysis (Starback et al. 1999) may constitute the final member in a hypothetical quartet of $\mathrm{Y}_{1}$-like genes whose ortholog may also remain to be discovered in mammals. If different lineages of vertebrates have retained distinct copies of ancestral duplicates, one may need information on chromosomal localization to confirm that they are true orthologs rather than paralogs. These chromosomal mapping data provide opportunities for positional cloning strategies to find expected additional members of gene families, and has already been demonstrated to be a fruitful approach (Katsanis et al. 1996).

\section{METHODS}

\section{Screening of Porcine Phage and BAC Libraries}

A genomic phage (LambdaGEM-11, Promega) library of a Norwegian landrace pig was screened at intermediate stringency as described previously (Tornsten et al. 1998) with the human NPY4R and mouse NPY6R clones as probes. A partial porcine NPY1R cDNA clone (provided by Mona Byström and Jonas Ekstrand, Astra Hässle, Umeå, Sweden) was used in high stringency $\left(60^{\circ} \mathrm{C}\right)$ hybridizations and washes with $0.5 \times \mathrm{SSC}$, $0.1 \%$ SDS. A genomic BAC (pBeloBac11) library of a large white boar with fivefold coverage organized into pools (RogelGaillard et al. 1999) was screened using PCR with pig NPY2Rspecific primers (provided by Mona Byström and Jonas Ekstrand, Astra Hässle, Umeå, Sweden). Amplifications were performed in a $25-\mu \mathrm{l}$ reaction volume containing, $0.2 \mu \mathrm{M}$ each primer (5'-CAAACAGTGGAAATGAAGA-3' and 5' TCAGTACAGGCAACAATCTCAAAGTCCGG-3'), $200 \mu \mathrm{m}$ dNTPs, $2 \mathrm{~mm} \mathrm{MgCl}_{2}, 10 \mathrm{ng}$ of DNA template, and 1 unit of Amplitaq DNA polymerase (Perkin Elmer), under the following cycling conditions: $94^{\circ} \mathrm{C}$ for $1 \mathrm{~min}, 53^{\circ} \mathrm{C}$ for $1 \mathrm{~min}$, and $72^{\circ} \mathrm{C}$ for $1 \mathrm{~min}$ for 35 cycles.

\section{DNA Sequencing and Analyses}

All sequencing was done according to recommended protocols with ABI Prism dye terminator cycle sequencing ready reaction kit (Perkin Elmer). Extension products were analyzed on the ABI PRISM 310 Genetic Analyzer (Perkin Elmer) automated sequencer. Sequences were compiled in Sequencher (Gene Codes) and aligned with Lasergene (DNASTAR) software, CLUSTAL method (default settings) with the exception of the NPY1R intron sequences, which were aligned by the Jotun Hein method. Sequences for construction of the phy- logenetic tree were amino acid sequences from the regions between and including the first and last transmembrane regions without the third intracellular loop, as these regions are more conserved. The amino acid sequences were also aligned by the Clustal method and a neighbor-joining tree was drawn using PHYLIP software (http://evolution.genetics. washington.edu/phylip.html). Gaps were treated as data and were not excluded from the calculations. The strength of the tree topology was tested by bootstrap analysis with 1000 replicates.

\section{Field Inversion Gel Electrophoresis}

The NPY5R containing phage was digested with the restriction endonuclease SfiI to remove the insert from the phage arms. The products and molecular weight standards were run on a $1 \%$ agarose gel with $180^{\circ}$ field inversion gel electrophoresis at a ratio of $3: 1$, forward (9 Volt) to reverse (6 Volt) ratio (Bio-Rad).

\section{Long-range PCR}

Long-range PCR (EXPAND Long Template PCR System, Boehringer Mannheim) was performed on the NPY1R and NPY5Rcontaining phage clones to estimate the distance from the phage arms to the coding region of the gene. The SP6 (5'CGATTTAGGTGACACTATAG-3') or T7 (5'-AATACGACTCACTATAG-3') primers, located in the phage arms, were used in combination with a reverse primer from NPY1R (5'TTCTCATCTCCTTCTGTTTC-3') and NPY5R (5'GGAGAGCAAATGGCAAGG-3'). The reaction was performed in a final volume of $50 \mu \mathrm{l}$, consisting of $1 \times$ EXPAND Long Template PCR System buffer 3, 20 pmole of each primer, 0.4 mM each dNTP, 2 units of EXPAND Long Template PCR System enzyme mix, and $20 \mathrm{ng}$ of phage template. Cycling started with an initial 2-min denaturation at $94^{\circ} \mathrm{C}$, this was followed by 35 cycles of $94^{\circ} \mathrm{C}$ for $30 \mathrm{sec}, 50^{\circ} \mathrm{C}$ for $30 \mathrm{sec}, 68^{\circ} \mathrm{C}$ for $12 \mathrm{~min}$, and a final extension of $68^{\circ} \mathrm{C}$ for $10 \mathrm{~min}$. The products were run out on a $0.8 \%$ agarose gel, specific products were obtained only using the SP6 primer in combination with either gene-specific reverse primer, giving fragment sizes of $4.1 \mathrm{~kb}$ for the NPY5R-containing phage and $7.2 \mathrm{~kb}$ for the NPY1R-containing phage.

\section{FISH Mapping}

The NPY1R and NPY4R-containing phage and the NPY2R BAC were physically assigned by FISH mapping on metaphase spreads according to Tornsten et al. (1998). The distance between the NPY1R and NPY5R-containing phage clones was estimated with fiber-FISH as described elsewhere (Sjoberg et al. 1997), in which signal detection, chromosome identification, imaging, and other details have also been described.

\section{Somatic Cell Hybrid Panel Mapping}

The panel developed by Yerle et al. (1996) was used in amplifications performed in a $20-\mu$ l reaction volume containing, $0.2 \mu \mathrm{M}$ of each porcine NPY6R primer (5'-GTCCTCTTAGAGACACAGTTCC-3' and 5'-CGGCTTTAGCATTAAGTGC-3'), 0.2 mM dNTPs, $1.5 \mathrm{~mm} \mathrm{MgCl}_{2}, 0.05 \% \mathrm{~W}-1,20$ mM tris (pH 8.4), 50 $\mathrm{mm} \mathrm{KCl}, 20 \mathrm{ng}$ of DNA template and 1 unit of Taq DNA polymerase (Life Technologies). Cycling conditions were as follows $1 \mathrm{~min}$ initial denaturation at $94^{\circ} \mathrm{C}$, followed by $94^{\circ} \mathrm{C}$ for $50 \mathrm{sec}, 54^{\circ} \mathrm{C}$ for $30 \mathrm{sec}$, and $72^{\circ} \mathrm{C}$ for $1 \mathrm{~min}, 30 \mathrm{sec}$ for 5 cycles, then $94^{\circ} \mathrm{C}$ for $30 \mathrm{sec}, 54^{\circ} \mathrm{C}$ for $30 \mathrm{sec}$, and $72^{\circ} \mathrm{C}$ for 1 min $30 \mathrm{sec}$ for 37 cycles, with a final extension of $5 \mathrm{~min}$ at $72^{\circ} \mathrm{C}$. This was used as template $(1 \mu \mathrm{l})$ for another PCR (as 
above, without the initial denaturation). The gene localization was deduced by the internet resource, http:// www.toulouse.inra.fr/lgc/pig/hybrid.htm.

\section{ACKNOWLEDGMENTS}

Mona Byström and Jonas Ekstrand kindly provided PCR primers and partial cDNA clones for pig NPY1R and NPY2R. This work was supported by the Swedish Natural Science Research Council.

The publication costs of this article were defrayed in part by payment of page charges. This article must therefore be hereby marked "advertisement" in accordance with 18 USC section 1734 solely to indicate this fact.

\section{REFERENCES}

Amores, A., A. Force, Y.L. Yan, L. Joly, C. Amemiya, A. Fritz, R.K. Ho, J. Langeland, V. Prince, and Y.L. Wang et al. 1998. Zebrafish hox clusters and vertebrate genome evolution. Science 282: $1711-1714$.

Blomqvist, A.G. and H. Herzog. 1997. Y-receptor subtypes-how many more? Trends Neurosci. 20: 294-298.

Bockaert, J. and J.P. Pin. 1999. Molecular tinkering of G protein-coupled receptors: An evolutionary success. EMBO J. 18: $1723-1729$.

Burkhoff, A., D.L. Linemeyer, and J.A. Salon. 1998. Distribution of a novel hypothalamic neuropeptide Y receptor gene and it's absence in rat. Brain Res. Mol. Brain Res. 53: 311-316.

Cardenas, M.L., A. Cornish-Bowden, and T. Ureta. 1998. Evolution and regulatory role of the hexokinases. Biochim. Biophys. Acta 1401: 242-264.

Cardinaud, B., K.S. Sugamori, S. Coudouel, J.D. Vincent, H.B. Niznik, and P. Vernier. 1997. Early emergence of three dopamine D1 receptor subtypes in vertebrates. Molecular phylogenetic, pharmacological, and functional criteria defining D1A, D1B, and D1C receptors in European eel Anguilla anguilla. J. Biol. Chem. 272: $2778-2787$.

Coulier, F., P. Pontarotti, R. Roubin, H. Hartung, M. Goldfarb, and D. Birnbaum. 1997. Of worms and men: An evolutionary perspective on the fibroblast growth factor (FGF) and FGF receptor families. J. Mol. Evol. 44: 43-56.

David-Watine, B., C. Goblet, D. de Saint Jan, S. Fucile, V. Devignot, P. Bregestovski, and H. Korn. 1999. Cloning, expression and electrophysiological characterization of glycine receptor alpha subunit from zebrafish. Neuroscience 90: 303-317.

Ellegren, H., M. Fredholm, I. Edfors-Lilja, A.K. Wintero, and L. Andersson. 1993. Conserved synteny between pig chromosome 8 and human chromosome 4 but rearranged and distorted linkage maps. Genomics 17: 599-603.

Feng, Y., C.C. Broder, P.E. Kennedy, and E.A. Berger. 1996. HIV-1 entry cofactor: functional cDNA cloning of a seven-transmembrane, G protein-coupled receptor. Science 272: $872-877$.

Fronicke, L., B.P. Chowdhary, H. Scherthan, and I. Gustavsson. 1996. A comparative map of the porcine and human genomes demonstrates ZOO- FISH and gene mapping-based chromosomal homologies. Mamm. Genome 7: 285-290.

Fryxell, K.J. 1995. The evolutionary divergence of neurotransmitter receptors and second-messenger pathways. J. Mol. Evol. 41: $85-97$.

Fuhlendorff, J., N.L. Johansen, S.G. Melberg, H. Thogersen, and T.W Schwartz. 1990. The antiparallel pancreatic polypeptide fold in the binding of neuropeptide Y to Y1 and Y2 receptors. J. Biol. Chem. 265: 11706-11712.

Gehlert, D.R. 1998. Multiple receptors for the pancreatic polypeptide (PP-fold) family: Physiological implications. Proc. Soc. Exp. Biol. Med. 218: 7-22.
Gerald, C., M.W. Walker, L. Criscione, E.L. Gustafson, C. Batzl-Hartmann , K.E. Smith, P. Vaysse, M.M. Durkin, T.M. Laz, D.L. Linemeyer et al. 1996. A receptor subtype involved in neuropeptide-Y-induced food intake. Nature 382: 168-171.

Goureau, A., M. Yerle, A. Schmitz, J. Riquet, D. Milan, P. Pinton, G. Frelat, and J. Gellin. 1996. Human and porcine correspondence of chromosome segments using bidirectional chromosome painting. Genomics 36: 252-262.

Gregor, P., Y. Feng, L.B. DeCarr, L.J. Cornfield, and M.L. McCaleb. 1996. Molecular characterization of a second mouse pancreatic polypeptide receptor and its inactivated human homologue. $J$. Biol. Chem. 271: 27776-27781.

Herzog, H.,M. Baumgartner, C. Vivero, L.A. Selbie, B. Auer, and J. Shine. 1993a. Genomic organization, localization, and allelic differences in the gene for the human neuropeptide Y Y1 receptor. J. Biol. Chem. 268: 6703-6707.

Herzog, H., Y.J. Hort, J. Shine, and L.A. Selbie. 1993b. Molecular cloning, characterization, and localization of the human homolog to the reported bovine NPY Y3 receptor: Lack of NPY binding and activation. DNA Cell Biol. 12: 465-471.

Herzog, H., K. Darby, H. Ball, Y. Hort, A. Beck-Sickinger, and J. Shine. 1997. Overlapping gene structure of the human neuropeptide Y receptor subtypes Y1 and Y5 suggests coordinate transcriptional regulation. Genomics 41: 315-319.

Holland, P.W., J. Garcia-Fernandez, N.A. Williams, and A. Sidow. 1994. Gene duplications and the origins of vertebrate development. Dev. Suppl.: 125-133.

Hort, Y., E. Baker, G.R. Sutherland, J. Shine, and H. Herzog. 1995. Gene duplication of the human peptide YY gene (PYY) generated the pancreatic polypeptide gene (PPY) on chromosome 17q21.1. Genomics 26: 77-83.

Hughes, A.L. 1999. Phylogenies of developmentally important proteins do not support the hypothesis of two rounds of genome duplication early in vertebrate history. J. Mol. Evol. 48: 565-576.

Jazin, E.E., H. Yoo, A.G. Blomqvist, F. Yee, G. Weng , M. W. Walker, J. Salon, and D. Larhammar. 1993. A proposed bovine neuropeptide Y (NPY) receptor cDNA clone, or its human homologue, confers neither NPY binding sites nor NPY responsiveness on transfected cells. Regul. Pept. 47: 247-258.

Johansson, M., H. Ellegren, and L. Andersson. 1995. Comparative mapping reveals extensive linkage conservation-but with gene order rearrangements-between the pig and the human genomes. Genomics 25: 682-690.

Katsanis, N., J. Fitzgibbon, and E.M.C. Fisher. 1996. Paralogy mapping: Identification of a region in the human $\mathrm{MHC}$ triplicated onto human chromosomes 1 and 9 allows the prediction and isolation of novel PBX and NOTCH loci. Genomics 35: 101-108.

Larhammar, D. 1996. Evolution of neuropeptide Y, peptide YY and pancreatic polypeptide. Regul. Pept. 62: 1-11.

Larhammar, D., A.-K. Arvidsson, M.M. Berglund, I. Lundell, E. Salaneck C. Söderberg, P. Starbäck, A. Wraith and D. R. Gehlert. 1997. Evolution of neuropeptide $Y$ and its receptors. In Proceedings of the Thirteenth International Congress of Comparative Endocrinology (ed. S. Kawashima and S. Kikuyama.) pp. 551-557. Monduzzi Editore, Japan.

Larhammar, D., C. Soderberg, and I. Lundell. 1998. Evolution of the neuropeptide Y family and its receptors. Ann. N.Y. Acad. Sci. 839: $35-40$.

Larsen, N.J., S. Marklund, K.A. Kelly, M. Malek, C.K. Tuggle, M. Yerle, and M.F. Rothschild. 1999. New insights into porcine-human synteny conservation. Mamm. Genome. 10: $488-491$.

Lee, C.C. and R.J. Miller. 1998. Is there really an NPY Y3 receptor? Regul. Pept. 75-76: 71-78.

Loetscher, M., T. Geiser, T. O'Reilly, R. Zwahlen, M. Baggiolini and Bo Moser. 1994. Cloning of a human seven-transmembrane domain receptor, LESTR, that is highly expressed in leukocytes. $J$. Biol. Chem. 269: 232-237.

Lundell, I., M.A. Statnick, D. Johnson, D.A. Schober, P. Starbäck, D.R. Gehlert, and D. Larhammar. 1996. The cloned rat 
pancreatic polypeptide receptor exhibits profound differences to the orthologous receptor. Proc. Natl. Acad. Sci. 93: 5111-5115.

Lundin, L.G. 1993. Evolution of the vertebrate genome as reflected in paralogous chromosomal regions in man and the house mouse. Genomics 16: 1-19.

Lutz, C.M., W.N. Frankel, J.E. Richards, and D.A. Thompson. 1997a. Neuropeptide Y receptor genes on human chromosome 4q31-q32 map to conserved linkage groups on mouse chromosomes 3 and 8. Genomics 41: 498-500.

Lutz, C.M., J.E. Richards, K.L. Scott, S. Sinha, T.L. Yang-Feng, W.N Frankel, and D.A. Thompson. 1997b. Neuropeptide Y receptor genes mapped in human and mouse: Receptors with high affinity for pancreatic polypeptide are not clustered with receptors specific for neuropeptide Y and peptide YY. Genomics 46: $287-290$.

Malmstrom, R.E., T. Hokfelt, J.A. Bjorkman, C. Nihlen, M. Bystrom, A.J. Ekstrard, and J.N. Lundburg. 1998. Characterization and molecular cloning of vascular neuropeptide $\mathrm{Y}$ receptor subtypes in pig and dog. Regul. Pept. 75-76: 55-70.

Matsumoto, M., T. Nomura, K. Momose, Y. Ikeda, Y. Kondou, H. Akiho, J. Togami, Y. Kimura, M. Okada, and T. Yamaguchi. 1996 Inactivation of a novel neuropeptide Y/peptide YY receptor gene in primate species. J. Biol. Chem. 271: 27217-27220.

Michel, M.C., A. Beck-Sickinger, H. Cox, H.N. Doods, H. Herzog, D. Larhammar, R. Quirion, T. Schwartz, and T. Westfall. 1998. XVI. International Union of Pharmacology recommendations for the nomenclature of neuropeptide Y, peptide YY, and pancreatic polypeptide receptors. Pharmacol. Rev. 50: 143-150.

Morgan, R.O., D.W. Bell, J.R. Testa, and M.P. Fernandez. 1998. Genomic locations of ANX11 and ANX13 and the evolutionary genetics of human annexins. Genomics 48: 100-110.

Newfeld, S.J., R.G. Wisotzkey, and S. Kumar. 1999. Molecular evolution of a developmental pathway: Phylogenetic analyses of transforming growth factor-beta family ligands, receptors and Smad signal transducers. Genetics 152: 783-795.

Oberlin, E., A. Amara, F. Bachelerie, C. Bessia, J.L. Virelizier, F. Arenzana-Seisdedos, O. Schwartz, J.M. Heard, I. Clark-Lewis, D.F. Legler et al. 1996. The CXC chemokine SDF-1 is the ligand for LESTR/fusin and prevents infection by T-cell-line-adapted HIV-1. Nature 382: 833-835.

O'Brien, S.J., M. Menotti-Raymond, W.J. Murphy, W.G. Nash, J. Wienberg R. Stanyon, N.G. Copeland, N.A. Jenkins, J.E. Womack and J.A. Marshall Graves. 1999. The promise of comparative genomics in mammals. Science 286: 458-481.

O'Shea, D., D.G. Morgan, K. Meeran, C.M. Edwards, M.D. Turton, S.J. Choi, M M. Heath, I. Gunn, G.M. Taylor, J.K. Howard et al. 1997. Neuropeptide $Y$ induced feeding in the rat is mediated by a novel receptor. Endocrinology 138: 196-202.

Pebusque, M.J., F. Coulier, D. Birnbaum, and P. Pontarotti. 1998. Ancient large-scale genome duplications: Phylogenetic and linkage analyses shed light on chordate genome evolution. Mol. Biol. Evol. 15: 1145-1159.

Rettenberger, G., C. Klett, U. Zechner, J. Kunz, W. Vogel and H. Hameister. 1995. Visualization of the conservation of synteny between humans and pigs by heterologous chromosomal painting. Genomics 26: 372-378.

Rimland, J., W. Xin, P. Sweetnam, K. Saijoh, E.J. Nestler and R.S. Duman. 1991. Sequence and expression of a neuropeptide $Y$ receptor cDNA. Mol. Pharmacol. 40: 869-875.

Rogel-Gaillard, C.N. Bourgeaux, A. Billault, M. Vaiman, and P. Chardon. 1999. Construction of a swine BAC library: Application to the characterization and mapping of porcine type $\mathrm{C}$ endoviral elements. Cytogenet. Cell Genet. 85: 205-211.

Rohrer, G.A. 1999. Mapping four genes from human chromosome 4 to porcine chromosome 8 further develops the comparative map for an economically important chromosome of the swine genome. Anim. Genet. 30: 60-62.

Rose, P.M., J.S. Lynch, S.T. Frazier, S.M. Fisher, W. Chung, P. Battaglino, Z. Fathi, R. Leibel and P. Fernandes. 1997. Molecular genetic analysis of a human neuropeptide $\mathrm{Y}$ receptor. The human homolog of the murine "Y5" receptor may be a pseudogene. J. Biol. Chem. 272: 3622-3627.

Rousset, D., F. Agnes, P. Lachaume, C. Andre, and F. Galibert. 1995. Molecular evolution of the genes encoding receptor tyrosine kinase with immunoglobulinlike domains. J. Mol. Evol. 41: $421-429$.

Ruddle, F.H., K.L. Bentley, M.T. Murtha, and N. Risch 1994. Gene loss and gain in the evolution of the vertebrates. Dev. Suppl : 155-161.

Schughart, K., C. Kappen, and F.H. Ruddle. 1989. Duplication of large genomic regions during the evolution of vertebrate homeobox genes. Proc. Natl. Acad. Sci. 86: 7067-7071.

Sidow, A. 1996. Gen(om)e duplications in the evolution of early vertebrates. Curr. Opin. Genet. Dev. 6: 715-722.

Sjoberg, A., L.J. Peelman, and B.P. Chowdhary. 1997. Application of three different methods to analyse fibre-FISH results obtained using four lambda clones from the porcine MHC III region. Chromosome Res. 5: 247-253.

Starbäck, P., I. Lundell, R. Fredriksson, M.M. Berglund, Y.L. Yan, A. Wraith, C. Söderberg, J. H. Postlethwait, and D. Larhammar. 1999. Neuropeptide Y receptor subtype with unique properties cloned in the zebrafish: The zYa receptor. Brain Res. Mol. Brain Res. 70: $242-252$.

Tornsten, A., A. Wraith, D. Larhammar, and B.P. Chowdhary. 1998. FISH mapping of the porcine NPY5 gene to chromosome 8p11. Mamm. Genome 9: 262-263.

Yerle, M., G. Echard, A. Robic, A. Mairal, C. Dubut-Fontana, J. Riquet, P. Pinton, D. Milan, Y. Lahbib-Mansais, and J. Gellin. 1996. A somatic cell hybrid panel for pig regional gene mapping characterized by molecular cytogenetics. Cytogenet. Cell Genet. 73: 194-202.

Yerle, M., Y. Lahbib-Mansais, P. Pinton, A. Robic, A. Goureau, D. Milan, and J. Gellin. 1997. The cytogenetic map of the domestic pig. Mamm. Genome 8: 592-607.

Received September 17, 1999; accepted in revised form January 11, 2000. 


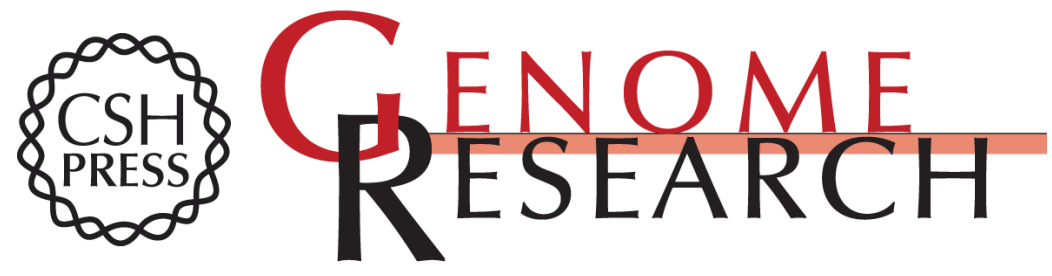

\section{Evolution of the Neuropeptide Y Receptor Family: Gene and Chromosome Duplications Deduced from the Cloning and Mapping of the Five Receptor Subtype Genes in Pig}

Amanda Wraith, Anna Törnsten, Patrick Chardon, et al.

Genome Res. 2000 10: 302-310

Access the most recent version at doi:10.1101/gr.10.3.302

References This article cites 54 articles, 16 of which can be accessed free at:

http://genome.cshlp.org/content/10/3/302.full.html\#ref-list-1

\section{License}

Email Alerting

Receive free email alerts when new articles cite this article - sign up in the box at the Service top right corner of the article or click here.

\section{Affordable, Accurate Sequencing.}

To subscribe to Genome Research go to:

https://genome.cshlp.org/subscriptions 